\title{
Preliminary observations on fluids incubated with Wuchereria bancrofti using the immunochromatographic test
}

\author{
Observações preliminares de fluidos incubados com Wuchereria bancrofti \\ usando o teste imunocromatográfico
}

\author{
Gerusa Dreyer ${ }^{1,2,3}$, Joaquim Norões ${ }^{3,4}$, Reinalda Lanfredi ${ }^{5}$, Renato Lins ${ }^{3}$, \\ Aleksandra Oliveira-Menezes ${ }^{5}$ and José Figueredo-Silva ${ }^{3,6}$
}

\begin{abstract}
To assess the performance of the immunochromatographic test for filariasis, adult Wuchereria bancrofti worms were incubated under different conditions. The tests were strongly positive with incubation fluids from both living and mechanically damaged females. Negative results were observed with incubation fluids from all male worms and from intact dead females.
\end{abstract}

Key-words: Wuchereria bancrofti. Adult worm. Immunochromatographic filariasis test. Antigen. Immunodiagnosis.

\section{RESUMO}

Para a valiar o desempenho do teste imunocromatográfico para filariose, vermes adultos de Wuchereria bancrofti foram incubados em diferentes condições. Os testes foram fortemente positivos com fluidos de incubação de fêmeas vivas e danificadas mecanicamente. Resultados negativos foram obtidos com fluidos de todos os machos e de fêmeas mortas intactas.

Palavras-chaves: Wuchereria bancrofti. Verme adulto. Teste imunocromatográfico para filariose. Antígeno. Imunodiagnóstico.

The demonstration, in 1946, that parasite antigen is present in the blood of subjects with filarial infection ${ }^{5}$ provided the foundation for the more recent development of antigen detection assays for Bancroftian filariasis cases using monoclonal antibodies. These are known as the $0 \mathrm{~g} 4 \mathrm{C} 3$ test $^{7}$ and immunochromatographic test (ICT) ${ }^{9}$. The commercially available ICT provides an unprecedent sensitive and rapid method (taking just a few minutes) for diagnosing adult worm infection in Bancroftian filariasis cases. To further explore the sensitivity of the ICT diagnostic test, living adult Wuchereria bancrofti were obtained at the time of surgery from two microfilaremic patients who had signed an informed consent statement and previously received antifilarial treatment. These worms were incubated in vitro and supernatants were tested for filarial antigen.

At the time of surgery for hydrocele repair, a segment of lymphatic vessel containing living adult Wuchereria bancrofti worms was excised from each patient. The vessel segments were placed in a Petri dish with sterile $0.9 \%$ saline solution at room temperature, incised with scissors, and for each patient, one living female and one living male worm actively emerged from the vessel. The male and female worms were placed in separate Petri dishes and gently washed three times with sterile saline.

Term definitions. Female worm: longer worm with living embryos seen inside the uterus on microscopic examination (100X); male worm: shorter worm with a coiled caudal end seen on microscopic examination (100X); living worm: active and intact in appearance and, when observed with naked eye, exhibiting patterns of continuous movement characteristic of those seen on ultrasound, described previously as the filaria dance sign (FDS) ${ }^{1}$; dead worm: inactive for at least 15 minutes, with no subsequent movement detected by the naked eye; mechanically disrupted worm: a worm that had died spontaneously in vitro, with subsequent disruption of the cuticle using forceps.

\footnotetext{
1. Núcleo de Ensino Pesquisa e Assistência em Filariose, Hospital das Clínicas, Universidade Federal de Pernambuco, Recife, PE. 2. Centro de Pesquisas Aggeu Magalhães, Fundação Oswaldo Cruz, Recife, PE. 3. Organização Não governamental Amaury Coutinho para Doenças Endêmicas e Tropicais, Recife, PE. 4. Departamento de Cirurgia, Centro de Ciências da Saúde, Universidade Federal de Pernambuco, Recife, PE. 5. Laboratório de Biologia de Helmintos Otto Wucherer, Instituto de Biofísica Carlos Chagas Filho, Centro de Ciências da Saúde, Universidade Federal do Rio de Janeiro, Rio de Janeiro, RJ. 6. Núcleo de Ensino e Pesquisa em Patologia, Faculdade de Ciências Médicas, Universidade Estadual do Piauí, Teresina, PI. Financial support: Non-governmental organization Amaury Coutinho; CNPq and FAPERJ Address to: Dr ${ }^{\mathrm{a}}$ Gerusa Dreyer. Organização Não governamental Amaury Coutinho para Doenças Endêmicas e Tropicais. Rua Conselheiro Portela 665/Sala 120, Graças, 52020-030 Recife, PE.

Telefax: 558134264348

e-mail: dreyer-g@uol.com.br

Recebido para publicação em: 03/08/2006

Aceito em: 28/01/2008
} 
Table 1 - Immunochromatographic test results using saline (patient n-1) or RPMI medium (patient no 2) incubated with living, dead and mechanically damaged adult male and female Wuchereria bancrofti worms that were surgically removed from intrascrotal lymphatic vessels.

\begin{tabular}{|c|c|c|c|c|c|}
\hline Worm status & $\begin{array}{l}\text { Worm } \\
\text { gender }\end{array}$ & $\begin{array}{l}\text { Patient } n^{0} 1 \\
\text { ICT/0g } 4 \mathrm{C} 3 \\
\end{array}$ & Incubation time/fluid/temperature & $\begin{array}{l}\text { Patient } \mathrm{n}^{0} 2 \\
\text { ICT }\end{array}$ & Incubation time/fluid/temperature \\
\hline Alive & $\begin{array}{c}\text { male } \\
\text { female }\end{array}$ & $\begin{array}{l}-/-* * * \\
+/+* * *\end{array}$ & $\begin{array}{l}45 \text { minutes/saline/room temperature } \\
45 \text { minutes/saline/ room temperature }\end{array}$ & $\begin{array}{l}- \\
+ \\
+\end{array}$ & $\begin{array}{l}60 \text { minutes } / \mathrm{RPMI} / 37^{\circ} \mathrm{C} \\
60 \text { minutes } / \mathrm{RPMI} / 37^{\circ} \mathrm{C}\end{array}$ \\
\hline Dead* & $\begin{array}{c}\text { male } \\
\text { female }\end{array}$ & $\begin{array}{l}-/ \mathrm{ND} \\
-/ \mathrm{ND} \\
\end{array}$ & $\begin{array}{l}60 \text { minutes/saline/room temperature } \\
60 \text { minutes/saline/room temperature }\end{array}$ & $\begin{array}{l}\mathrm{ND} \\
\mathrm{ND}\end{array}$ & $\begin{array}{l}\mathrm{NA} \\
\mathrm{NA}\end{array}$ \\
\hline Disrupted & $\begin{array}{c}\text { male } \\
\text { female }\end{array}$ & $\begin{array}{l}-/ \mathrm{ND} \\
+/ \mathrm{ND}\end{array}$ & $\begin{array}{l}\text { NA/saline/room temperature } \\
\text { NA/saline/room temperature }\end{array}$ & $\begin{array}{l}\text { ND } \\
\text { ND }\end{array}$ & $\begin{array}{l}\mathrm{NA} \\
\mathrm{NA}\end{array}$ \\
\hline
\end{tabular}

ICT: immunochromatographic test, -: negative ICT, +: positive ICT, ND: not done, NA: not applicable

* The male worm died spontaneously after 2 hours and 45 minutes, and the female died after 3 hours and 15 minutes, when left at room temperature.

** 0g4C3 male fluid: 20.7UI; Og4C3 female fluid: $183.7 \mathrm{UI}$; the cutoff considered for serum specimens at the Centers for Disease Control (CDC) at the time that the tests were performed was $140 \mathrm{UI}$

To assess ICT performance, the worms were incubated under different conditions. Aliving and either intact or mechanically disrupted dead worms were incubated in Petri dishes with saline or RPMI-1640 (Gibco Invitrogen Corporation) for different lengths of time (Table 1). The incubation fluid from each worm was collected and immediately tested in vitro. The incubation fluid derived from living or dead intact females was filtered through a $0.22 \mu \mathrm{m}$ Millipore membrane in order to remove any microfilaria from the supernatant. The ICT was performed in accordance with the manufacturers'

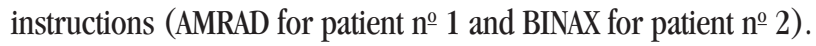
The cards were read immediately after applying $100 \mu l$ of incubation fluid at zero, 5, 10 and 15 minutes, before considering the results to be positive or negative. Additional readings were made at 6, 12 and 24 hours thereafter. Serum aliquots from known Wuchereria bancrofti-infected and uninfected individuals, pure saline and RPMI medium underwent ICT in parallel with incubation fluids. The incubation fluid from living male and female worms was also stored at $-20^{\circ} \mathrm{C}$ and tested using $0 \mathrm{~g} 4 \mathrm{C} 3$-ELISA assay, by means of the same technique as described elsewhere for serum samples ${ }^{3}$. No microfilaria was detected in the Millipore membranes. A positive band appeared immediately (i.e. before control line development) with incubation fluids from females but not from male worms. Details of the findings can be seen in Table 1 . The additional card readings at 6, 12, and 24 hours remained unchanged. The ICT cards used as controls tested negative with saline, RPMI and uninfected individuals and positive with serum from infected patients.

The results from this study, although preliminary, demonstrate that the source of antigen binding for MoAb AD12.1 may be gender-dependent, since only the females produced a positive test confirmed by $0 \mathrm{~g} 4 \mathrm{C} 3$. Markedly positive test results from incubation fluid from living adult female worms indicate that the secretory-excretory antigen is released in vitro, perhaps continuously. Furthermore, release of antigen into the incubation fluid after mechanically damaging the worm suggests that the antigen is also stored inside the parasite. Even after damage and death of the adult worm in vivo, it is conceivable that the release of antigen will continue for a certain time. Experimental evidence suggests this possibility. When animals infected with Brugia were treated with a highly effective adulticidal drug (CGP 20376), antigen clearance was incomplete in some animals even when mature and immature infections were successfully cleared ${ }^{2}$. The extent to which this occurs following the death of adult Wuchereria bancrofti in vivo is unknown. On the other hand, within this context, it seems reasonable that the antigen released by dead worms will disappear more rapidly from circulation in patients whose worms are calcified ${ }^{68}$. Indeed, calcification of dead parasite constitutes an important factor in terminating the tissue inflammatory response, thereby reducing or even abolishing the source of parasite material ${ }^{4}$. The negative ICT results associated with male worms are puzzling, and suggest that unisex infection with male Wuchereria bancrofti may not be detected by antigen tests. Unfortunately, so far, it has not been possible to determine the gender of adult Wuchereria bancrofti by ultrasound or other available diagnostic tools, prior to surgery. On the other hand, male worms, being smaller than females, may release smaller quantities of the antigen. In this case, the fluid might have tested positive if the incubation period were longer or a larger number of males were incubated, but the test was negative even using the disrupted males. In addition, it was not possible to establish the age of the (male) worms, and this could be related to physiological processes of synthesis and secretion of antigenic substances that react with the ICT.

Given the importance of the ICT as a widely used tool for monitoring infection rates, both at the individual and at the community level, further research is recommended in order to clarify the source of antigen recognized by the test and to confirm these preliminary findings. Understanding ICT performance better will be essential for monitoring the successful elimination of lymphatic filariasis as a public health problem.

\section{ACKNOWLEDGEMENTS}

The authors thank the patients enrolled in the study; Amaury Coutinho Non-Governmental Organization, CNPq, CAPES-PROCAD and FAPERJ for the financial support; Dr. Patrick Lammie for the $0 \mathrm{~g} 4 \mathrm{C} 3$ assays and valuable suggestions on the original manuscript; and Dr. David Addiss for very fruitful discussion on the subject.

\section{REFERENCES}

1. Amaral F, Dreyer G, Figueredo-Silva J, Norões J, Cavalcanti A, Samico SF, Santos A, Coutinho A. Living adult worms detected by ultrasonography in human bancroftian filariasis. The American Journal of Tropical Medicine and Hygiene 50: $753-757,1994$ 
2. Chandrashekar R, Subramanyam D, Well GJ. Effect of CGP 20376 on Brugia malay and parasite antigenemia in jirds. The Journal of Parasitology 77: 479-482, 1991.

3. Chanteau S, Glaziou P, Moulia-Pelat JP, Plichart C, Luquiaud P, Cartel JL. Low positive predictive value of anti-Brugia malayi IgG and IgG4 serology for the diagnosis of Wuchereria bancrofti. Transactions of the Royal Society of Tropical Medicine and Hygiene 88: 661-662, 1994.

4. Figueredo-Silva J, Norões J, Cedenho A, Dreyer G. Histopathology of bancroftian filariasis revisited: the role of the adult worm in the lymphatic vessel disease. Annals of Tropical Medicine and Parasitology 96: 531-541, 2002.

5. Franks MB. Specific soluble antigen in the blood of filarial patients. The Journal of Parasitology 32: 400-406, 1946.
6. Michael P. Filariasis: histopathologic study. United States Naval Medical Bulletin 45: 225-226, 1945

7. More SJ, Copeman DB. A highly specific and sensitive monoclonal antibody-based ELISA for the detection of circulating antigen in bancroftian filariasis. Annals of Tropical Medicine and Parasitology 41: 403-406, 1990.

8. O'Connor FW, Golden R, Auckinclos H. The roentgen demonstration of calcified filaria bancrofti in human tissue. The American Journal of Roentgenology, Radium Therapy, and Nuclear Medicine 23: 495-502, 1930.

9. Weil GJ, Lammie PJ, Weiss N. The ICT filariasis test: a rapid-format antigen test for diagnosis of bancroftian filariasis. Parasitology Today 13: 401-404, 1997. 